\title{
Implementation of geographical information systems for the study of diseases caused by vector-borne arboviruses in Southeast Asia: A review based on the publication record
}

\author{
Ajib Diptyanusa, ${ }^{1}$ Lutfan Lazuardi, ${ }^{2}$ Retnadi Heru Jatmiko ${ }^{3}$ \\ ${ }^{1}$ Department of Parasitology, Faculty of Medicine, Public Health and Nursing, Universitas Gadjah Mada, \\ Jalan Farmako, Sekip Utara; ${ }^{2}$ Department of Health Policy and Management, Faculty of Medicine, Public \\ Health and Nursing, Universitas Gadjah Mada, Jalan Farmako, Sekip Utara; ${ }^{3}$ Centre for Remote Sensing \\ and Geographical Information System (PUSPICS), Universitas Gadjah Mada, Sekip Utara, Yogyakarta, \\ Indonesia
}

\begin{abstract}
The spread of mosquito-borne diseases in Southeast Asia has dramatically increased in the latest decades. These infections include dengue, chikungunya and Japanese Encephalitis (JE), high-burden viruses sharing overlapping disease manifestation and vector distribution. The use of Geographical Information Systems (GIS) to monitor the dynamics of disease and vector distribution can assist in disease epidemic prediction and public health interventions, particularly in Southeast Asia where sustained high temperatures drive the epidemic spread of these mosquito-borne viruses. Due to lack of accurate data, the spatial and temporal dynamics of these mosquito-borne viral disease transmission countries are poorly understood, which has limited disease control effort. By following studies carried out on these three viruses across the region in a specific time period revealing general patterns of research activities and characteristics, this review finds the need to improve decision-support by disease mapping and management. The results presented, based on a publication search with respect to diseases due to arboviruses, specif-
\end{abstract}

Correspondence: Ajib Diptyanusa, Department of Parasitology, Faculty of Medicine, Public Health and Nursing, Universitas Gadjah Mada, Jalan Farmako, Sekip Utara, Yogyakarta 55281, Indonesia,

Tel.: +628122962999 - Fax: +62274546215

E-mail: ajib.diptyanusa@mail.ugm.ac.id

Key words: GIS; mosquito-borne viruses; dengue, chikungunya; Japanese encephalitis; mapping; surveillance; Southeast Asia.

Conflict of interests: the authors declare no potential conflict of interests.

Received for publication: 31 January 2020.

Accepted for publication: 14 April 2020

(C) Copyright: the Author(s), 2020

Licensee PAGEPress, Italy

Geospatial Health 2020; 15:862

doi:10.4081/gh.2020.862

This article is distributed under the terms of the Creative Commons Attribution Noncommercial License (CC BY-NC 4.0) which permits any noncommercial use, distribution, and reproduction in any medium, provided the original author(s) and source are credited. ically dengue, chikungunya and Japanese encephalitis, should improve opportunities for future studies on the implementation of GIS in the control of mosquito-borne viral diseases in Southeast Asia.

\section{Introduction}

The expansion of mosquito-borne infections has increased dramatically since the 1970 s along with an increasing number of clinical cases (Rossi et al., 2018). These diseases include dengue and chikungunya, the viruses that cause them are both transmitted by Aedes mosquitoes (Manore et al., 2014). Japanese Encephalitis (JE), caused by a yet another vector-borne virus, has drawn attention from the public health sector worldwide (Erlanger et al., 2009). Although this virus is primarily transmitted by Culex rather than Aedes mosquitoes, the geographical distribution of these mosquito species overlap, especially in Southeast Asian countries (Leta et al., 2018; Pearce et al., 2018; Lam-Phua et al., 2019). Since this region possesses the highest burden of these emerging and re-emerging diseases, large epidemics overburdening local healthcare systems may occur at any time (van Panhuis et al., 2015). In order to detect rapid changes in the incidence rate of infectious diseases, as well as identifying and characterizing the syndromes, disease surveillance and prompt management of epidemic potential are mandatory (Christaki, 2015). Given their mode of transmission, emerging and re-emerging mosquito-borne diseases may expeditiously overwhelm available healthcare facilities both at regional and global levels, hence the need of immediate preventive and control measures (Heymann and Rodier, 2001; Christaki, 2015). Disease emergence can be forecast by simulation or statistical modelling based on disease incidence, population density and environmental factors (Weiss and McMichael, 2004; Jones et al., 2008; Ajelli et al., 2010; Morse et al., 2012; Lipkin, 2013). Epidemic modelling is also commonly used in the control of vector-borne diseases (Barrios et al., 2012).

The use of spatial data and remote sensing to monitor the dynamics of diseases and vectors can assist in disease prediction and identification of hotspots where emerging pathogens are likely to occur (Ford et al., 2009; Morse et al., 2012). Risk-based approaches based on Geographical Information Systems (GIS) can improve the efficiency of disease surveillance and signal early warning for areas at increased risk for disease transmission (Christaki, 2015). In Southeast Asia where sustained high temper- 
atures drive the epidemic spread of mosquito-borne viruses on a continental scale, applications for GIS in disease control effective epidemic prediction can be utmost beneficial (van Panhuis et al., 2015). Furthermore, the increase in international travel and trade, change in land use, as well as the growth of informal settlements in developing countries play a role in the proliferation of these diseases (Sutherst, 2004). However, the dynamics are poorly understood, which limits efficient control due to lack of accurate and detailed spatiotemporal information and demographic data, political constraints and data management issues (Brian and Lawrence, 2001). The urgent need for control of mosquito-borne viral diseases is further supported by the Asia Pacific Strategy for Emerging Diseases (APSED), an approach aimed at strengthening national and regional capacities to manage and respond to emerging disease threats (WHO, 2018). The current review aims at identification of the implementation of GIS in studies related to highburden mosquito-borne viral diseases in Southeast Asian countries including dengue, chikungunya and JE. It emphasizes the need to implement decision-support capabilities in disease mapping and management using GIS in countries and aims to improve opportunities for future studies on the use of GIS in the control of mosquito-borne viral diseases.

\section{Materials and Methods}

We attempted to cover different types of implementation of GIS in studies related to mosquito-borne viral diseases, particularly dengue, chikungunya and Japanese encephalitis. In the initial step, we surveyed the titles and abstracts of electronic articles through (http://www.ncbi.nlm.nih.gov/pubmed/) database with search terms including: geographic information system, GIS, remote sensing, spatial, temporal, spatio-temporal, map, dengue, chikungunya, Japanese encephalitis, Aedes and Culex. We included research articles published from January 2005 through September 2019 written in English. In the second step, we selectively included studies performed in Southeast Asian countries, including Indonesia, Singapore, Malaysia, Thailand, Myanmar, Laos, Vietnam, Cambodia, Philippines, and Brunei. We excluded grey literatures, unpublished data, review articles, letters to the editor and research articles not related to the use of GIS. Study flow chart is depicted in Figure 1. After the bibliographic search, we identified a total of 644 publications. In the first step, we excluded 581 articles due to topic irrelevance (564), duplicate articles (10) and abstract only (7). Following full-text review of 63 articles, 26 articles were excluded due to topic irrelevance and unfitting article types. Finally, a total of 37 complete articles underwent analysis and were included in this review (Table 1). The analysis focused on the various uses of health GIS including disease seroprevalence mapping, vector distribution mapping, spatial relationships and causal factors in disease distribution, disease risk mapping and transmission models, and decision support for disease intervention.

\section{Discussion}

The bibliographic search identified a total of 644 publications. Following title and abstract screening, 14 articles were excluded due to topic irrelevance and unfitting article type. Finally, a total of 37 complete articles underwent full-text review and were included in this review (Table 1).

\section{Disease seroprevalence mapping}

The most common application of GIS in the field of public health is the identification of disease case distributions, incidence or prevalence (Musa et al., 2013). We identified two studies related to seroepidemiological disease mapping, as shown in Table 2. A study conducted in four states of Peninsular Malaysia assessed chikungunya IgG seropositivity in both rural and urban communities (Azami et al., 2013). The study demonstrated $5.9 \%$ seropositivity in clustered distribution in both areas, with individuals living in rural settings being more at risk. Individuals aged 45-64 years were found to be the age group most prevalent for seropositivity. Another study was conducted in Lao PDR to the evaluate serological status of individuals against dengue and JE (Vallee et al., 2009). The results showed that IgG-positivity were most frequently found in adults living in the city centre, whereas IgM-positive individuals were more likely to live in the periphery. The findings of these studies can assist decisions-making on implementation of dengue control and/or when to use of dengue and JE vaccination, as they also provide age-specific seroprevalence and seroconversion data (Carabali et al., 2017). Younger individuals are less likely to have been exposed to either virus, and this population may be considered as the target group for vaccination programs (Flasche et al., 2016). Moreover, increasing seroconversion

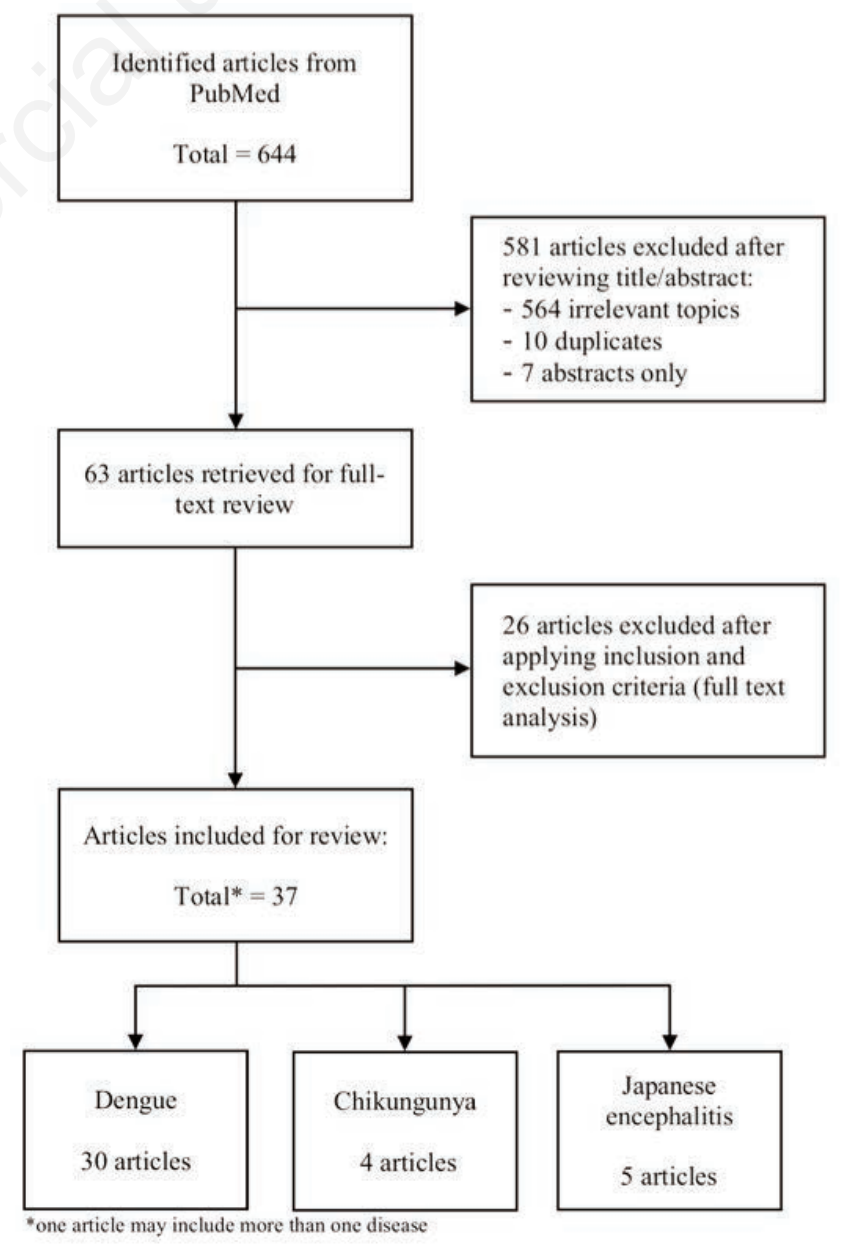

Figure 1. Flowchart of literature selection process. 
rate with age is important as it indicates disease transmission in an area (Toan et al., 2015; Villar et al., 2015). These profiles imply that existing vector control measures in study areas are inadequate, and that novel vector control strategies are urgently needed (Sasmono et al., 2018). Only few seroepidemiological studies along with utilisation of GIS have been identified in this review, possibly due to the difficulty and the cost of conducting long-term, cohort-based studies. Therefore, most of the available data regarding disease seroprevalence were derived from passive disease surveillance, leading to significant uncertainties in disease controllability, such as the basic reproductive rate $\left(\mathrm{R}_{0}\right)$ that can be used to determine the critical vaccination fraction to eliminate disease transmission and lessen the economic burden (Johansson et al., 2011; Supadmi et al., 2019).

\section{Disease vector distribution mapping}

Other than mapping the disease distribution itself, several studies utilised GIS for mapping the vector distribution, which is essential in monitoring expansion of the disease into previously non-endemic areas (Ong et al., 2019). Studies on Aedes mosquitoes distribution were mostly reported from Thailand (Chansang and Kittayapong, 2007; Sarfraz et al., 2012; Boonklong and Bhumiratana, 2016), and these studies mainly reported the types of water containers or habitats suitable for mosquito breeding. The ecology and the availability of potential breeding sites differs in urban and rural settings, and one study focused on that showing that the higher the urban-rural gradient, the greater the risk for seasonal and geographical spread of Aedes mosquitoes, (Boonklong and Bhumiratana, 2016). Interestingly, another Thai study showed that Ae. aegypti and Ae. albopictus entomological indices (house index, Breteau index, container index) were found to be influenced by the season and land use (Sarfraz et al., 2012), whereas another study conducted in Malaysia showed the opposite
(Aziz et al., 2014). This might be due to the latter study was based on urban dengue hotspots, while the former study was conducted in villages with different endemicities. In addition, a larval GISsupported survey of Ae. aegypti mosquitoes in Thailand showed a significant clustering of larvae within 10-20 m radius in the study area (Chansang and Kittayapong, 2007). Along with larval indices, dengue entomological indices may represent a fairly close scenario of vector habitat suitability, however the indices were seen to remain weak in predicting dengue cases (Sarfraz et al., 2012). The study details are described further in Table 3. A number of studies utilised geopositioned occurrence data of JE cases and its vectors in evaluating the spread of the vectors and their habitats. Several clusters of some Culex species were observed in Vietnam, where small clusters were influenced by the presence of cattle, but not by the proximity of rice fields to the house compounds (Hasegawa et al., 2008). This might be due to local practice, in which people washed animal sheds and hence created polluted ground pools that served as potential breeding sites for these mosquitoes. A multinational study was conducted in several Asian countries in predicting the environmental suitability for Cx tritaeniorhynchus distribution, which showed that countries in South Asia and East Asia were the primary locations for the distribution of this mosquito species (Longbottom et al., 2017). The study also predicted some spots of $C x$. tritaeniorhynchus distribution in Southeast Asian countries. However, due to the sparse availability of data for these countries, it remains unclear if these areas were already inhabited or have yet to be colonised by the species. When GIS and statistical models are combined, spatial distribution of disease vectors can be predicted. Particularly in the presence of a changing environment due to human disruptions or climate change, an impact on mosquito vectors is inevitable, hence longitudinal monitoring of vectors is necessary (Higa, 2011).

Table 1. Number of studies and countries of study origin.

\begin{tabular}{|c|c|c|c|c|c|}
\hline \multirow[t]{2}{*}{ Country } & \multicolumn{2}{|c|}{ Studied diseases } & \multirow{2}{*}{\multicolumn{2}{|c|}{ Japanese encephalitis }} & \multirow{2}{*}{ Multiple diseases Total } \\
\hline & Dengue & Chikungunya & & & \\
\hline Brunei & - & - & - & - & - \\
\hline Cambodia & - & - & - & - & - \\
\hline Indonesia & 4 & - & - & - & 4 \\
\hline Lao PDR & - & - & - & $1^{* *}$ & 1 \\
\hline Malaysia & 6 & 1 & - & - & 7 \\
\hline Myanmar & - & - & - & - & - \\
\hline Philippines & - & - & - & - & - \\
\hline Singapore & 2 & - & - & - & 2 \\
\hline Thailand & 13 & 2 & - & - & 15 \\
\hline Vietnam & 1 & - & 1 & - & 2 \\
\hline Multiple countries* & 2 & - & 3 & $1^{* * *}$ & 6 \\
\hline Total & 28 & 3 & 4 & 2 & 37 \\
\hline
\end{tabular}

${ }^{*}$ Can involve several or all Southeast Asian countries; **Dengue, JE; ***Dengue, Chikungunya.

Table 2. Selected studies on disease seroprevalence mapping.

\begin{tabular}{|c|c|c|c|c|}
\hline Author & Publication year & Country & Disease(s) studied & Core findings \\
\hline Azami et al. & 2013 & Malaysia & Chikungunya & Anti- IgG seropositivity clustered in both rural and urban communities \\
\hline Vallee et al. & 2009 & Lao PDR & $\begin{array}{l}\text { Dengue, } \\
\text { Japanese encephalitis }\end{array}$ & $\begin{array}{l}\text { Anti-IgG positivity frequently found in the city centre with IgM-positivity } \\
\text { more common in the periphery }\end{array}$ \\
\hline
\end{tabular}




\section{Spatial relationships and causal factors in disease distribution}

In order to understand the disease transmission dynamics and to plan vector control measures, identification of high-risk areas and seasonal variations of disease transmission is essential. A majority of the identified studies dealt with dengue, identifying disease distribution patterns and potential risk factors of transmission (Table 4). Varying results were reported, as different study sites had their own local profiles. A study conducted in remote villages in Sarawak, Malaysia showed the presence of dengue cases in the absence of Aedes entomological indices, and consequently also of the principal vector of dengue, with the niche probably filled by Ae. albopictus, which is more widely distributed in Sarawak regardless of remoteness of the villages studied (Cheah et al., 2006). Another study performed in Vietnam suggested that the timing and magnitude of annual dengue epidemics were influenced by local biological and ecological drivers, including vector survival, biting behaviour and virus replication within the vector (Cuong et al., 2013).

Clustering of dengue cases was observed in many studies (Vanwambeke et al., 2006; Salje et al., 2012; Yoon et al., 2012; Thomas et al., 2015; Salje et al., 2017) demonstrating focal transmission due to the low flight range of Aedes mosquitoes $(<100 \mathrm{~m})$ (Bouzid et al., 2016). However, the roles of population growth, human travel and urbanisation have been suggested to drive dengue spatiotemporal clustering and spread in the Asia-Pacific region (Banu et al., 2014). Smaller clusters suggest that most of the cases were transmitted via short-distance human movement (Guzzetta et al., 2018) and that environmental factors might play a role in the development of such focal clusters (Auchincloss et al., 2012). This evidence is strengthened by a multinational study that have demonstrated a higher population density and shorter distances in countries were predominant factors, characterising both dengue and chikungunya outbreaks, reflect a higher probability of vectors and infected individuals moving between neighbouring countries with similar climatic conditions (Rossi et al., 2018). These traits infer that disease control strategies should be focused not only on peridomestic environment surrounding index cases, but also in other gathering places following human movement (Stoddard et al., 2013).

The complexity of the spread of mosquito-borne viruses is further added by the presence of climate change manifested as either alteration in rainfall patterns, flooding or an increased chance of extreme events. Such changes cause an altered vector ecology and population dynamics leading to geographical expansion of disease vectors and increased threats of disease transmission (Baylis, 2017; Whitehorn and Yacoub, 2019). Spatial variations of dengue cases have been reported in several studies (Jeefoo et al., 2011; Aziz et al., 2012; Astuti et al., 2019; Husnina et al., 2019; Xu et al., 2019), and they show that dengue incidences are strongly associated with rainfall, temperature and humidity. One study also demonstrated that dengue case distribution had a tendency of increased clustering during periods of low rainfall, while heavy rainfall had the opposite effect (Aziz et al., 2012). Although most studies claimed that climatic factors are determinants of dengue, other study reported no significant correlation between climatic factors and dengue incidence (Kesetyaningsih et al., 2018). This might be due to difficulties in statistical analysis (Lai, 2018), as most of the climatic data used in the study performed by Kesetyaningsih et al. (2018) were range-type data (minimum-maximum value, mean value and cumulative value). Interestingly, a multinational study identified that the combination of climate, virus and population conditions in Southeast Asia might have initiated the spread of the dengue virus under the influence by particularly high temperatures during a strong El Niño episode (van Panhuis et al., 2015). This inter-annual climate phenomenon may result in fluctuations of draught and flooding which directly increase the epidemics of mosquito-borne viruses, including dengue and chikungunya (Anyamba et al., 2019). Nevertheless, the relationship between climate change and mosquito-borne viruses expansion may not always be linear, for instance, heavy rainfall may also flush away aquatic stages of the vector in breeding places (Seidahmed and Eltahir, 2016; Whitehorn and Yacoub, 2019). The identification of dengue clusters and risk factors associated with disease clustering

Table 3. Studies on disease vector distribution mapping.

\begin{tabular}{|c|c|c|c|c|}
\hline Author & Publication year & Country & Disease(s) studied & Core findings \\
\hline Aziz et al. & 2014 & Malaysia & $\begin{array}{l}\text { Ae. aegypti } \\
\text { Ae. albopictus }\end{array}$ & $\begin{array}{l}\text { Mosquito hotspots of various density where land use does not } \\
\text { affect mosquito populations }\end{array}$ \\
\hline Boonklong et al. & 2016 & Thailand & $\begin{array}{l}\text { Ae. aegypti } \\
\text { Ae. albopictus }\end{array}$ & $\begin{array}{l}\text { Seasonal distribution of vectors differing between urban and rural areas } \\
\text { according to types of water container }\end{array}$ \\
\hline Chansang et al. & 2007 & Thailand & $\begin{array}{l}\text { Ae. aegypti } \\
\text { Ae. albopictus }\end{array}$ & Clustering of larvae within $10-20 \mathrm{~m}$ radius of houses \\
\hline Ong et al. & 2019 & Singapore & $\begin{array}{l}\text { Ae. aegypti } \\
\text { Ae. albopictus }\end{array}$ & $\begin{array}{l}\text { Expansion into previously non-dengue areas with increasing Ae. aegypti } \\
\text { habitat percentage }\end{array}$ \\
\hline Sarfraz et al. & 2012 & Thailand & $\begin{array}{l}\text { Ae. aegypti } \\
\text { Ae. albopictus }\end{array}$ & $\begin{array}{l}\text { Settlements around gasoline stations and in vicinity of marsh or rice } \\
\text { paddy favourable areas for mosquito vector habitats }\end{array}$ \\
\hline Longbottom et al. & 2017 & $\begin{array}{l}\text { Indonesia, } \\
\text { Malaysia, } \\
\text { Philippines, } \\
\text { Thailand, } \\
\text { Vietnam }\end{array}$ & CX. tritaeniorhynchus & $\begin{array}{l}\text { Environmental suitability for } \\
\text { Cx. tritaeniorhynchus primarily located across countries in } \\
\text { South and East Asia }\end{array}$ \\
\hline Hasegawa et al. & 2008 & Vietnam & $\begin{array}{l}\text { CX. vishnui subgroup } \\
\text { CX. gelidus } \\
\text { Cx. quinquefasciatus }\end{array}$ & $\begin{array}{l}\text { Mosquito clusters not observed at scales larger than house compound } \\
\text { units; presence of cattle might influence abundance of the vectors }\end{array}$ \\
\hline
\end{tabular}


are essential tools to target suitable disease control policies, particularly in designing timely disease surveillance with a focus on intense disease control activities, such as insecticide spraying and active case-finding (Vincenti-Gonzalez et al., 2017; Guzzetta et al., 2018).
As most of this study results demonstrated small disease clusters, the implementation of control interventions at the neighbourhood level may be significantly useful in reducing dengue transmission rather than random interventions.

Table 4. Studies on spatial relationships and causal factors in disease distribution.

\begin{tabular}{|c|c|c|c|c|}
\hline Author & ublication year & Country & Studied disease(s) & Major findings \\
\hline Astuti et al. & 2019 & Indonesia & Dengue & $\begin{array}{l}\text { Incidence in children spatially varied and clustered at the village level; } \\
\text { seasonal patterns of dengue incidence strongly associated with rainfall, } \\
\text { temperature and humidity }\end{array}$ \\
\hline Aziz et al. & 2012 & Malaysia & Dengue & $\begin{array}{l}\text { Spatial distribution more clustered with low mean rainfall, while cases } \\
\text { more dispersed during the rainy season }\end{array}$ \\
\hline Banu et al. & 2014 & $\begin{array}{l}\text { Indonesia, } \\
\text { Lao PDR, } \\
\text { Malaysia, } \\
\text { Myanmar, } \\
\text { Philippines, } \\
\text { Singapore, } \\
\text { Thailand, } \\
\text { Vietnam }\end{array}$ & Dengue & $\begin{array}{l}\text { Clusters of endemicity geographically expanded in Asia-Pacific over } 50 \text { years } \\
\text { with most likely cluster in Vietnam, Lao PDR and Thailand, } \\
\text { possibly due to population growth, travel, urbanisation and lack } \\
\text { of effective vector control. }\end{array}$ \\
\hline Cheah et al. & 2006 & Malaysia & Dengue & $\begin{array}{l}\text { Risk factors including container density, house density, egg count per } \\
\text { positive ovitraps in and around houses not correlated with number of cases }\end{array}$ \\
\hline Cuong et al. & 2013 & Vietnam & Dengue & $\begin{array}{l}\text { Annual epidemics occurring later in Ho Chi Minh City than in other provinces } \\
\text { with timing and magnitude correlated in nearby districts suggesting influence } \\
\text { of local biological and ecological drivers }\end{array}$ \\
\hline Husnina et al. & 2019 & Indonesia & Dengue & $\begin{array}{l}\text { Seasonal pattern closely related to minimum temperature and relative } \\
\text { humidity with forest cover reduction associated with increasing risk of } \\
\text { dengue in only one study area }\end{array}$ \\
\hline Jeefoo et al. & 2011 & Thailand & Dengue & $\begin{array}{l}\text { Case distribution clustered in villages with those on the urban fringe } \\
\text { reporting higher incidences; outbreak, movement and spread patterns } \\
\text { associated with climatic factors but not related to entomologic and } \\
\text { epidemiologic factors }\end{array}$ \\
\hline Kesetyaningsih et al. & 2018 & Indonesia & Dengue & $\begin{array}{l}\text { Annual incidents in all sub-districts clustered with no environmental } \\
\text { factors closely related to dengue incidence }\end{array}$ \\
\hline Salje et al. & 2012 & Thailand & Dengue & $\begin{array}{l}\text { Localised transmission within 1-km radius with clustering of particular dengue } \\
\text { virus serotypes in the neighbourhood }\end{array}$ \\
\hline Salje et al. & 2017 & Thailand & Dengue & $\begin{array}{l}\text { Approximately } 60 \% \text { of case pairs separated }<200 \mathrm{~m} \text { from same virus } \\
\text { transmission chain supporting focal transmission at neighbourhood level }\end{array}$ \\
\hline Thomas et al. & 2015 & Thailand & Dengue & $\begin{array}{l}\text { Focal spread of dengue virus within radius of } 120 \mathrm{~m} \text { from the index case was } \\
\text { associated with the mosquito vector }\end{array}$ \\
\hline van Panhuis et al. & 2015 & $\begin{array}{l}\text { Cambodia, } \\
\text { Thailand, } \\
\text { Lao PDR, } \\
\text { Vietnam, } \\
\text { Malaysia, } \\
\text { Singapore, } \\
\text { Philippines }\end{array}$ & Dengue & $\begin{array}{l}\text { Local climate, virus and population conditions may have ignited emergence } \\
\text { and spread of dengue virus influenced by high temperatures during strong El } \\
\text { Niño episode together with population movement in central Thailand, } \\
\text { eastern Mekong and southern Philippines }\end{array}$ \\
\hline Vanwambeke et al. & 2006 & Thailand & Dengue & $\begin{array}{l}\text { Weather pattern and dengue infection rate not correlated, whereas land cover } \\
\text { playing important role in infection determinant by providing habitats }\end{array}$ \\
\hline Yoon et al. & 2012 & Thailand & Dengue & $\begin{array}{l}\text { Spatiotemporal clustering in children with mosquitoes detected within } \\
100 \text {-m radius and transmission showing an over-dispersion pattern }\end{array}$ \\
\hline Xu et al. & 2019 & Thailand & Dengue & Distinct seasonality of cases, mostly affected by climatic factors \\
\hline Rossi et al. & 2018 & $\begin{array}{l}\text { Brunei, } \\
\text { Cambodia, } \\
\text { Indonesia, } \\
\text { Lao PDR, } \\
\text { Malaysia, } \\
\text { Myanmar, } \\
\text { Singapore, } \\
\text { Thailand, } \\
\text { Vietnam }\end{array}$ & $\begin{array}{l}\text { Dengue } \\
\text { Chikungunya }\end{array}$ & $\begin{array}{l}\text { Higher population density and shorter distances among countries } \\
\text { with outbreaks predominant factors characterising both dengue } \\
\text { and chikungunya outbreaks in Southeast Asian countries }\end{array}$ \\
\hline
\end{tabular}




\section{Disease risk mapping and transmission models}

Traditionally, maps were used only when identifying and monitoring associations between location, environment, and disease (Musa et al., 2013). However, the use of mapping with respect to diseases has evolved into transmission models predicting future disease distribution trends. Table 5 describes identified studies related to risk mapping and transmission models supported by georeferenced disease data. risk mapping can be highly useful in guiding vector control programs, mainly for disease surveillance and epidemic mitigation efforts (Ong et al., 2018). In order to classify certain areas as of low or high risk for disease transmission, several factors need to be identified, e.g., a study on dengue risk prediction mapping conducted in Selangor, Malaysia identified human settle- ments coverage and non-agricultural areas as risk factors for dengue transmission (Cheong et al., 2014). Similarly, other studies also identified population density and types of land use as risk factors by dengue zone mapping (Nakhapakorn and Tripathi, 2005; Dom et al., 2013; Ong et al., 2018). Another study stratified regions according to vulnerability status of contracting dengue by using the Water-associated Disease Index (WADI) that comprises many elements including climate, land use, population density, type of housing, sanitation quality and sociodemographic factors (Dickin et al., 2013). However, the WADI might not represent all areas in the country equally well since the availability of detailed health data are lacking in some regions. To increase preparedness for potential dengue outbreaks, the public health sector in many

Table 5. Studies in disease risk mapping and transmission models.

\begin{tabular}{|c|c|c|c|c|}
\hline Author & Publication year & Country & Studied disease(s) & Major findings \\
\hline Cheong et al. & 2014 & Malaysia & Dengue & $\begin{array}{l}\text { Prediction map derived from several factors including human settlements } \\
\text { and non-agricultural areas, with large share of human settlements associated } \\
\text { with higher numbers of dengue cases }\end{array}$ \\
\hline Dickin et al. & 2013 & Malaysia & Dengue & $\begin{array}{l}\text { WADI* integrating social and biophysical components classifying study areas } \\
\text { into high and low vulnerability with urban environments particularly vulnerable }\end{array}$ \\
\hline Dom et al. & 2013 & Malaysia & Dengue & $\begin{array}{l}\text { Areas with different disseminations mainly influenced by land use and } \\
\text { population density with urban areas of high and moderate-high risk } \\
\text { areas when surrounded by massive developments }\end{array}$ \\
\hline Nakhapakorn et al. & 2005 & Thailand & Dengue & $\begin{array}{l}\text { Risk map generated by modelling with climatic factors as independent } \\
\text { variables with built-up areas constituting highest risk followed by agricultural areas }\end{array}$ \\
\hline Ong et al. & 2018 & Singapore & Dengue & $\begin{array}{l}\text { Risk mapping indicating predicted risk levels in agreement with dengue case } \\
\text { densities with numbers of clusters in high-risk areas almost } 8 \text { times that of } \\
\text { low-risk areas, which represented } 50 \% \text { of residential areas }\end{array}$ \\
\hline O'Reilly et al. & 2019 & Indonesia & Dengue & $\begin{array}{l}\text { Predicted spatial concentration of cases with highest risk in urban regions of } \\
\text { Java, West Kalimantan and northern Sumatra accounting for } 15 \% \text { of national } \\
\text { dengue burden }\end{array}$ \\
\hline Chadsuthi et al. & 2016 & Thailand & Chikungunya & $\begin{array}{l}\text { Mathematical modelling showing speed of transmission and incidence } \\
\text { in particular areas affected by climatic variations }\end{array}$ \\
\hline Chadsuthi et al. & 2018 & Thailand & Chikungunya & $\begin{array}{l}\text { Transmission model using human movement, temperature and rainfall } \\
\text { maximum likelihood fit of transmission demonstrating importance of human } \\
\text { movement and weather conditions for spread of the virus }\end{array}$ \\
\hline Miller et al. & 2012 & $\begin{array}{l}\text { Brunei, } \\
\text { Cambodia, } \\
\text { Indonesia, } \\
\text { Lao PDR, } \\
\text { Malaysia, } \\
\text { Myanmar, } \\
\text { Philippines, } \\
\text { Singapore, } \\
\text { Thailand, } \\
\text { Vietnam }\end{array}$ & Japanese encephalitis & $\begin{array}{l}\text { Ecological niche modelling based on environmental data demonstrating } \\
\text { that Vietnam, Cambodia and Thailand have }>50 \% \text { of land area with }>25 \% \\
\text { probability of JE vector presence, which is in line with observed risk of } \\
\text { increased numbers of human cases }\end{array}$ \\
\hline Samy et al. & 2018 & $\begin{array}{c}\text { Brunei } \\
\text { Cambodia } \\
\text { Indonesia } \\
\text { Lao PDR } \\
\text { Malaysia } \\
\text { Myanmar } \\
\text { Philippines } \\
\text { Singapore } \\
\text { Thailand } \\
\text { Vietnam }\end{array}$ & Japanese encephalitis & $\begin{array}{l}\text { Ecological model predicting an overlapping distribution of vectors } \\
\text { and reservoirs in high-risk countries including Myanmar, Lao PDR, Thailand, } \\
\text { Vietnam, Malaysia and Indonesia. }\end{array}$ \\
\hline
\end{tabular}


countries has developed dengue risk maps (Louis et al., 2014). By comparing risk-stratified areas for disease transmission over the years, identification of new or recurring risk areas can assist in prioritising areas for control efforts; hence effective deployment of resources (Ong et al., 2018). Furthermore, risk mapping or risk prediction mapping can potentially be implemented in other areas with similar environmental settings, particularly for diseases transmitted by similar vector species, such as dengue and chikungunya (Cheong et al., 2014). With the advancement of computational science, efforts of disease monitoring and epidemic simulation have been made possible by various types of modelling (Ajelli et al., 2010; Christaki, 2015). Mathematical modelling was used in estimating the burden of dengue in Indonesia (O'Reilly et al., 2019) finding a predicted highest risk of spatial concentration of dengue cases in the urban regions of Java, Kalimantan and Sumatra. The use of a transmission model of chikungunya virus spread in Thailand revealed that climatic variations and human movement affect the speed of virus transmission in particular areas (Chadsuthi et al., 2016; Chadsuthi et al., 2018). Ecological modelling was also used in predicting the risk of JE transmission in multinational studies (Miller et al., 2012; Samy et al., 2018) predicting an overlapping distribution of vectors and reservoirs in high-risk countries including Myanmar, Lao PDR, Thailand, Vietnam, Malaysia and Indonesia. Additionally, more than $25 \%$ probability of JE vector presence in over $50 \%$ of the land area of Vietnam, Cambodia and Thailand was predicted with an increasing risk of human JE cases in those areas. As mosquito-borne viruses are sensitive to climate fluctuations, modelling disease transmission in a series of unique climatic episodes, including an El Niño event, in Southeast Asia as done by Tipayamongkholgul et al. (2009) and Anyamba et al. (2019) will be very useful in future epidemic forecasting.

Disease transmission modelling improves our understanding of the role of disease mobility patterns and is an important instrument in assessing both past and current disease epidemics, which are needed for the preparation of future interventions (Christaki, 2015). However, mosquito-borne disease outbreaks are more challenging to predict due to the dynamics of mosquito ecology and human behaviour in different populations (Ford et al., 2009). As mosquito-borne viruses are sensitive to climate change (Ludwig et al., 2019), close monitoring of climatologic parameters is therefore essential to evaluate slight changes that may contribute to disease outbreak.

\section{Decision support for disease intervention}

By identifying high-risk areas and accurately modelling the flow of disease transmission, it is possible to target intervention efforts. Three such studies were identified and analysed in this review (Table 6). One of the studies was conducted in Indonesia and estimated the impact of releasing Wolbachia-infected mosquitoes. The results predicted that a nationwide Wolbachia campaign could avert up to $86 \%$ of dengue cases in areas with high transmission intensity, including urban areas of Java, Kalimantan and Sumatra (O'Reilly et al., 2019). In Thailand, two studies (Kittayapong et al., 2008; Thammapalo et al., 2012) adapted GIS for monitoring disease control interventions. One showed suppression of dengue transmission in treated areas by application of integrated vector control strategies, including source reduction, screening for water jars, application of Bacillus thuringiensis subspecies israelensis (Bti)-acting as biological pesticide, and insecticide-treated ovitraps (Kittayapong et al., 2008). The other study found that the coverage of space spraying was inadequate $(<100 \mathrm{~m}$ radius from index case) as evidenced by spreading of dengue infections and increasing number of cases with secondary infection despite timely spraying (Thammapalo et al., 2012). In countries with persistent transmission of mosquito-borne viruses, failure of disease control program should be suspected. A better monitoring and evaluation of disease surveillance and resource allocation for control programs are hence mandatory.

The number of epidemiological studies employing GIS in Southeast Asian countries and elsewhere has increased sharply in the past decade. However, not all of Southeast Asian countries have independently performed and published study national outcomes, e.g., Brunei, Cambodia, Myanmar and Philippines, which have instead been involved in large-scale, multinational studies. Possibly, due to the proportion of national budget available, these countries focused more on case finding and case management than disease surveillance and outbreak mitigation (Caballero-Anthony et al., 2015). Cambodia, Lao PDR, Myanmar, and Vietnam, i.e. countries in the Greater Mekong sub-region, might be more concerned in other high-burden, lethal mosquito-borne diseases such as malaria (Cui et al., 2012; Geng et al., 2019), which would explain the lack of research activities regarding mosquito-borne viral diseases. Political constraints and resource allocation may thus also have played a role for the outcomes (Brian and Lawrence, 2001).

In general, most of the identified studies emphasised identification of spatial relationship, risk mapping and transmission model of dengue infection, while publications regarding the use of GIS for research on chikungunya and JE were somewhat limited. Dengue contributes substantially to the economic and disease burden in Southeast Asia; higher than other mosquito-borne viral diseases (Shepard et al., 2013). Nevertheless, these two diseases share similar clinical, epidemiological and diagnostic features with dengue, therefore future studies on chikungunya and JE should be encouraged (O'Reilly et al., 2019). Factors that might contribute to the comparatively small number of published chikungunya- and

Table 6. Studies on decision support for disease intervention.

\begin{tabular}{|c|c|c|c|c|}
\hline Author & Publication year & Country & Studied disease(s) & Major findings \\
\hline O'Reilly et al. & 2019 & Indonesia & Dengue & $\begin{array}{l}\text { Nationwide long-term Wolbachia campaign preventing up to } 86 \% \text { of cases in } \\
\text { high-transmission areas }\end{array}$ \\
\hline Kittayapong et al. & 2008 & Thailand & Dengue & $\begin{array}{l}\text { Reduction of the number of Ae. aegypti mosquitoes in focal dengue-treated } \\
\text { areas by screening for water jars, application of Bti*-bacteria acting as } \\
\text { biological pesticide and insecticide-treated ovitraps }\end{array}$ \\
\hline Thammapalo et al. & 2012 & Thailand & Dengue & $\begin{array}{l}\text { Increased number of cases with secondary infection despite timely spraying } \\
\text { due to inadequate coverage of space spraying }\end{array}$ \\
\hline
\end{tabular}

*Bacillus thuringiensis subspecies israelensis. 
JE-related studies, could be that the disease burden due to these infections may be perceived to be less than other mosquito-borne diseases. Another reason could be that a majority of Southeast Asian countries have already deployed a national JE immunisation program (Heffelfinger et al., 2017), and that researchers focus on dengue and chikungunya as they assume that the epidemiology of these viruses is similar since they can share vectors.

\section{Conclusions}

GIS has shown great promise in location of high-risk areas and populations at risk, identification of areas in need of resources and allocation of effective resources for control. The current review has identified a number of published papers on the use of GIS in dengue, chikungunya, and JE in Southeast Asian countries. Independent studies in all countries should be encouraged, particularly with respect to chikungunya and JE considering the high burden and the overlapping distribution of their mosquito vectors. Only very limited seroprevalence studies and disease intervention monitoring based on GIS were identified. This is important as seropositive populations reflect a long-term burden and ongoing disease transmission in a given area. Monitoring of ongoing interventions using GIS is important as this can assist identifying areas with failed disease control strategies, thus optimising resource allocation in those areas. More focused control strategies are urgently needed yet challenging due to limited data (O'Reilly et al., 2019). There is a need for more integrated research activities with regard to all three diseases covered by this review, addressing knowledge gaps in the implementation of GIS in control strategies, including approaches from seroprevalence studies in determining target population for vaccination program to intervention monitoring.

\section{References}

Ajelli M, Gonçalves B, Balcan D, Colizza V, Hu H, Ramasco JJ, Merler S, Vespignani A, 2010. Comparing large-scale computational approaches to epidemic modeling: Agent-based versus structured metapopulation models. BMC Infect Dis 10:190. doi: 10.1186/1471-2334-10-190.

Anyamba A, Chretien J-P, Britch SC, Soebiyanto RP, Small JL, Jepsen R, et al, 2019. Global Disease Outbreaks Associated with the 2015-2016 El Niño Event. Sci Rep 9:1930. doi: 10.1038/s41598-018-38034-z.

Astuti EP, Dhewantara PW, Prasetyowati H, Ipa M, Herawati C, Hendrayana K, 2019. Paediatric dengue infection in Cirebon, Indonesia: a temporal and spatial analysis of notified dengue incidence to inform surveillance. Parasit Vectors 12:186. doi: 10.1186/s13071-019-3446-3.

Auchincloss AH, Gebreab SY, Mair C, Diez Roux AV, 2012. A review of spatial methods in epidemiology, 2000-2010. Ann Rev Public Health 33:107-22. doi: 10.1146/annurev-publhealth-031811-124655.

Azami NAM, Salleh SA, Shah SA, Neoh H-m, Othman Z, Zakaria SZS, et al, 2013. Emergence of chikungunya seropositivity in healthy Malaysian adults residing in outbreak-free locations: chikungunya seroprevalence results from the Malaysian Cohort. BMC Infect Dis 13:67. doi: 10.1186/1471-2334-1367.
Aziz S, Aidil RM, Nisfariza MN, Ngui R, Lim YA, Yusoff WS, et al, 2014. Spatial density of Aedes distribution in urban areas: a case study of breteau index in Kuala Lumpur, Malaysia. J Vector Borne Dis 51:91-6.

Aziz S, Ngui R, Lim YA, Sholehah I, Nur Farhana J, Azizan AS, et al, 2012. Spatial pattern of 2009 dengue distribution in Kuala Lumpur using GIS application. Trop Biomed 29:113-20.

Banu S, Hu W, Guo Y, Naish S, Tong S, 2014. Dynamic spatiotemporal trends of dengue transmission in the Asia-Pacific region, 1955-2004. PLoS One 9:e89440. doi: 10.1371/journal.pone.0089440.

Barrios JM, Verstraeten WW, Maes P, Aerts J-M, Farifteh J, Coppin P, 2012. Using the gravity model to estimate the spatial spread of vector-borne diseases. Int J Environ Res Public Health, 9:4346-64. doi: 10.3390/ijerph9124346.

Baylis M, 2017. Potential impact of climate change on emerging vector-borne and other infections in the UK. Environ Health 16:112. doi: 10.1186/s12940-017-0326-1.

Boonklong O, Bhumiratana A, 2016. Seasonal and Geographical Variation of Dengue Vectors in Narathiwat, South Thailand. Can J Infect Dis Med Microbiol 8062360. doi: $10.1155 / 2016 / 8062360$.

Bouzid M, Brainard J, Hooper L, Hunter PR, 2016. Public Health Interventions for Aedes Control in the Time of Zikavirus- A Meta-Review on Effectiveness of Vector Control Strategies. PLoS Negl Trop Dis 10:e0005176. doi: 10.1371/journal.pntd.0005176.

Brian EM, Lawrence AW, Jr, 2001. Geographic Information Systems in Developing Countries: Issues in Data Collection, Implementation and Management. Journal of Global Information Management (JGIM) 9:44-54. doi: 10.4018/jgim.2001100103.

Caballero-Anthony M, Cook A, Amul G, Sharma A, 2015. Health Governance and Dengue in Southeast Asia. Singapore: Centre for Non-Traditional Security Studies (NTS), Nanyang Technological University.

Carabali M, Lim JK, Velez DC, Trujillo A, Egurrola J, Lee KS, et al, 2017. Dengue virus serological prevalence and seroconversion rates in children and adults in Medellin, Colombia: implications for vaccine introduction. Int J Infect Dis 58:27-36. doi: 10.1016/j.ijid.2017.02.016.

Chadsuthi S, Althouse BM, Iamsirithaworn S, Triampo W, Grantz KH, Cummings DAT, 2018. Travel distance and human movement predict paths of emergence and spatial spread of chikungunya in Thailand. Epidemiol Infect 146:1654-62. doi: $10.1017 / \mathrm{s} 0950268818001917$.

Chadsuthi S, Iamsirithaworn S, Triampo W, Cummings DAT, 2016. The impact of rainfall and temperature on the spatial progression of cases during the chikungunya re-emergence in Thailand in 2008-2009. Trans R Soc Trop Med Hyg 110:12533. doi: $10.1093 /$ trstmh/trv114.

Chansang C, Kittayapong P, 2007. Application of mosquito sampling count and geospatial methods to improve dengue vector surveillance. Am J Trop Med Hyg 77:897-902. doi: 10.4269/ajtmh.2007.77.897.

Cheah WL, Chang MS, Wang YC, 2006. Spatial, environmental and entomological risk factors analysis on a rural dengue outbreak in Lundu District in Sarawak, Malaysia. Trop Biomed 23:85-96.

Cheong YL, Leitão PJ, Lakes T, 2014. Assessment of land use factors associated with dengue cases in Malaysia using Boosted 
Regression Trees. Spat Spatiotemporal Epidemiol 10:75-84. doi: 10.1016/j.sste.2014.05.002.

Christaki E, 2015. New technologies in predicting, preventing and controlling emerging infectious diseases. Virulence 6:558-65. doi: 10.1080/21505594.2015.1040975.

Cui L, Yan G, Sattabongkot J, Cao Y, Chen B, Chen X, et al, 2012. Malaria in the Greater Mekong Subregion: heterogeneity and complexity. Acta Trop 121:227-39. doi: 10.1016/j.actatropica. 2011.02.016.

Cuong HQ, Vu NT, Cazelles B, Boni MF, Thai KTD, Rabaa MA, et al, 2013. Spatiotemporal dynamics of dengue epidemics, southern Vietnam. Emerg Infect Dis 19:945-53. doi: 10.3201/eid1906.121323.

Dickin SK, Schuster-Wallace CJ, Elliott SJ, 2013. Developing a vulnerability mapping methodology: applying the water-associated disease index to dengue in Malaysia. PLoS One 8:e63584. doi: 10.1371/journal.pone.0063584.

Dom NC, Ahmad AH, Latif ZA, Ismail R, 2013. Measurement of dengue epidemic spreading pattern using density analysis method: retrospective spatial statistical study of dengue in Subang Jaya, Malaysia, 2006-2010. Trans R Soc Trop Med Hyg 107:715-22. doi: 10.1093/trstmh/trt073.

Erlanger TE, Weiss S, Keiser J, Utzinger J, Wiedenmayer K, 2009. Past, present, and future of Japanese encephalitis. Emerg Infect Dis 15:1-7. doi: 10.3201/eid1501.080311.

Flasche S, Jit M, Rodriguez-Barraquer I, Coudeville L, Recker M, Koelle K, et al, 2016. The Long-Term Safety, Public Health Impact, and Cost-Effectiveness of Routine Vaccination with a Recombinant, Live-Attenuated Dengue Vaccine (Dengvaxia): A Model Comparison Study. PLoS Med 13:e1002181. doi: 10.1371/journal.pmed.1002181.

Ford TE, Colwell RR, Rose JB, Morse SS, Rogers DJ, Yates TL, 2009. Using satellite images of environmental changes to predict infectious disease outbreaks. Emerg Infect Dis 15:1341-6. doi: 10.3201/eid1509.081334.

Geng J, Malla P, Zhang J, Xu S, Li C, Zhao Y, et al, 2019. Increasing trends of malaria in a border area of the Greater Mekong Subregion. Malar J 18:309. doi: 10.1186/s12936-0192924-6.

Guzzetta G, Marques-Toledo CA, Rosà R, Teixeira M, Merler S, 2018. Quantifying the spatial spread of dengue in a nonendemic Brazilian metropolis via transmission chain reconstruction. Nature Commun 9:2837. doi: 10.1038/s41467-01805230-4.

Hasegawa M, Tuno N, Yen NT, Nam VS, Takagi M, 2008. Influence of the distribution of host species on adult abundance of Japanese encephalitis vectors Culex vishnui subgroup and Culex gelidus in a rice-cultivating village in northern Vietnam. Am J Trop Med Hyg 78:159-68. doi: 10.4269/ajtmh. 2008.78.159.

Heffelfinger JD, Li X, Batmunkh N, Grabovac V, Diorditsa S, Liyanage JB, et al, 2017. Japanese Encephalitis Surveillance and Immunization - Asia and Western Pacific Regions, 2016. MMWR Morb Mortal Wkly Rep 66:579-83. doi: 10.15585/mmwr.mm6622a3.

Heymann DL, Rodier GR, 2001. Hot spots in a wired world: WHO surveillance of emerging and re-emerging infectious diseases. Lancet Infect Dis 1:345-53. doi: 10.1016/s1473-3099(01) 00148-7.

Higa Y, 2011. Dengue Vectors and their Spatial Distribution. Trop Med Health 39:17-27. doi: 10.2149/tmh.2011-S04.
Husnina Z, Clements ACA, Wangdi K, 2019. Forest cover and climate as potential drivers for dengue fever in Sumatra and Kalimantan 2006-2016: a spatiotemporal analysis. Trop Med Int Health 24:888-98. doi: 10.1111/tmi.13248.

Jeefoo P, Tripathi NK, Souris M, 2011. Spatio-temporal diffusion pattern and hotspot detection of dengue in Chachoengsao province, Thailand. Int J Environ Res Public Health 8:51-74. doi: 10.3390/ijerph8010051.

Johansson MA, Hombach J, Cummings DAT, 2011. Models of the impact of dengue vaccines: a review of current research and potential approaches. Vaccine 29:5860-8. doi: 10.1016/j.vaccine.2011.06.042.

Jones KE, Patel NG, Levy MA, Storeygard A, Balk D, Gittleman JL, et al, 2008. Global trends in emerging infectious diseases. Nature 451:990-3. doi: 10.1038/nature06536.

Kesetyaningsih TW, Andarini S, Sudarto, Pramoedyo H, 2018. Determination of Environmental Factors Affecting Dengue Incidence in Sleman District, Yogyakarta, Indonesia. Afr J Infect Dis 12:13-25. doi: 10.2101/Ajid.12v1S.3.

Kittayapong P, Yoksan S, Chansang U, Chansang C, Bhumiratana A, 2008. Suppression of dengue transmission by application of integrated vector control strategies at sero-positive GIS-based foci. Am J Trop Med Hyg 78:70-6. doi: 10.4269/ajtmh. 2008.78.70.

Lai YH, 2018. The climatic factors affecting dengue fever outbreaks in southern Taiwan: an application of symbolic data analysis. Biomed Eng Online 17:148. doi: 10.1186/s12938018-0575-4.

Lam-Phua SG, Yeo H, Lee RML, Chong CS, Png AB, Foo SY, et al, 2019. Mosquitoes (Diptera: Culicidae) of Singapore: Updated Checklist and New Records. J Med Entomol 56:10319. doi: 10.1093/jme/tjy154.

Leta S, Beyene TJ, De Clercq EM, Amenu K, Kraemer MUG, Revie CW, 2018. Global risk mapping for major diseases transmitted by Aedes aegypti and Aedes albopictus. Int J Infect Dis 67:25-35. doi: 10.1016/j.ijid.2017.11.026.

Lipkin WI, 2013. The changing face of pathogen discovery and surveillance. Nat Rev Microbiol 11:133-41. doi: 10.1038/nrmicro2949.

Longbottom J, Browne AJ, Pigott DM, Sinka ME, Golding N, Hay SI, et al, 2017. Mapping the spatial distribution of the Japanese encephalitis vector, Culex tritaeniorhynchus Giles, 1901 (Diptera: Culicidae) within areas of Japanese encephalitis risk. Parasit Vectors 10:148. doi: 10.1186/s13071-017-2086-8.

Louis VR, Phalkey R, Horstick O, Ratanawong P, Wilder-Smith A, Tozan Y, et al, 2014. Modeling tools for dengue risk mapping - a systematic review. Int J Health Geogr 13:50. doi: 10.1186/1476-072X-13-50.

Ludwig A, Zheng H, Vrbova L, Drebot MA, Iranpour M, Lindsay LR, 2019. Increased risk of endemic mosquito-borne diseases in Canada due to climate change. Can Commun Dis Rep 45:91-7. doi: 10.14745/ccdr.v45i04a03.

Manore CA, Hickmann KS, Xu S, Wearing HJ, Hyman JM, 2014. Comparing dengue and chikungunya emergence and endemic transmission in A. aegypti and A. albopictus. J Theor Biol 356:174-91. doi: 10.1016/j.jtbi.2014.04.033.

Miller RH, Masuoka P, Klein TA, Kim H-C, Somer T, Grieco J, 2012. Ecological niche modeling to estimate the distribution of Japanese encephalitis virus in Asia. PLoS Negl Trop Dis 6:e1678. doi: 10.1371/journal.pntd.0001678.

Morse SS, Mazet JAK, Woolhouse M, Parrish CR, Carroll D, 
Karesh WB, et al, 2012. Prediction and prevention of the next pandemic zoonosis. Lancet 380:1956-65. doi: 10.1016/S01406736(12)61684-5.

Musa GJ, Chiang P-H, Sylk T, Bavley R, Keating W, Lakew B, et al, 2013. Use of GIS Mapping as a Public Health Tool-From Cholera to Cancer. Health Serv Insights 6:111-6. doi: 10.4137/HSI.S10471.

Nakhapakorn K, Tripathi NK, 2005. An information value-based analysis of physical and climatic factors affecting dengue fever and dengue haemorrhagic fever incidence. Int J Health Geogr 4:13. doi: 10.1186/1476-072X-4-13.

O'Reilly KM, Hendrickx E, Kharisma DD, Wilastonegoro NN, Carrington LB, Elyazar IRF, et al, 2019. Estimating the burden of dengue and the impact of release of wMel Wolbachia-infected mosquitoes in Indonesia: a modelling study. BMC Med 17:172. doi: 10.1186/s12916-019-1396-4.

Ong J, Liu X, Rajarethinam J, Kok SY, Liang S, Tang CS, et al, 2018. Mapping dengue risk in Singapore using Random Forest. PLoS Negl Trop Dis 12:e0006587. doi: 10.1371/journal.pntd.0006587.

Ong J, Liu X, Rajarethinam J, Yap G, Ho D, Ng LC, 2019. A novel entomological index, Aedes aegypti Breeding Percentage, reveals the geographical spread of the dengue vector in Singapore and serves as a spatial risk indicator for dengue. Parasit Vectors 12:17. doi: 10.1186/s13071-018-3281-y.

Pearce JC, Learoyd TP, Langendorf BJ, Logan JG, 2018. Japanese encephalitis: the vectors, ecology and potential for expansion. J Travel Med 25:S16-S26. doi: 10.1093/jtm/tay009.

Rossi G, Karki S, Smith RL, Brown WM, Ruiz MOH, 2018. The spread of mosquito-borne viruses in modern times: A spatiotemporal analysis of dengue and chikungunya. Spat Spatiotemporal Epidemiol 26:113-25. doi: 10.1016/j.sste.2018.06.002.

Salje H, Lessler J, Endy TP, Curriero FC, Gibbons RV, Nisalak A, et al, 2012. Revealing the microscale spatial signature of dengue transmission and immunity in an urban population. Proc Natl Acad Sci USA 109:9535-8. doi: 10.1073/pnas.1120621109.

Salje H, Lessler J, Maljkovic Berry I, Melendrez MC, Endy T, Kalayanarooj S, et al, 2017. Dengue diversity across spatial and temporal scales: Local structure and the effect of host population size. Science 355:1302-6. doi: 10.1126/science.aaj9384.

Samy AM, Alkishe AA, Thomas SM, Wang L, Zhang W, 2018. Mapping the potential distributions of etiological agent, vectors, and reservoirs of Japanese Encephalitis in Asia and Australia. Acta Trop 188:108-17. doi: 10.1016/j.actatropica.2018.08.014.

Sarfraz MS, Tripathi NK, Tipdecho T, Thongbu T, Kerdthong P, Souris M, 2012. Analyzing the spatio-temporal relationship between dengue vector larval density and land-use using factor analysis and spatial ring mapping. BMC Public Health 12:853. doi: 10.1186/1471-2458-12-853.

Sasmono RT, Taurel A-F, Prayitno A, Sitompul H, Yohan B, Hayati $\mathrm{RF}$, et al, 2018. Dengue virus serotype distribution based on serological evidence in pediatric urban population in Indonesia. PLoS Negl Trop Dis 12:e0006616. doi: 10.1371/journal.pntd.0006616.

Seidahmed OME, Eltahir EAB, 2016. A Sequence of Flushing and Drying of Breeding Habitats of Aedes aegypti (L.) Prior to the Low Dengue Season in Singapore. PLoS Negl Trop Dis 10:e0004842. doi: 10.1371/journal.pntd.0004842.

Shepard DS, Undurraga EA, Halasa YA, 2013. Economic and Disease Burden of Dengue in Southeast Asia. PLoS Negl Trop Dis 7:e2055. doi: 10.1371/journal.pntd.0002055.

Stoddard ST, Forshey BM, Morrison AC, Paz-Soldan VA, Vazquez-Prokopec GM, Astete H, et al, 2013. House-to-house human movement drives dengue virus transmission. Proc Natl Acad Sci USA 110:994-9. doi: 10.1073/pnas.1213349110.

Supadmi W, Suwantika AA, Perwitasari DA, Abdulah R, 2019. Economic Evaluations of Dengue Vaccination in the Southeast Asia Region: Evidence from a Systematic Review. Value Health Reg Issues 18:132-44. doi: 10.1016/j.vhri.2019.02.004.

Sutherst RW, 2004. Global change and human vulnerability to vector-borne diseases. Clin Microbiol Rev 17:136-73. doi: 10.1128/cmr.17.1.136-173.2004.

Thammapalo S, Meksawi S, Chongsuvivatwong V, 2012. Effectiveness of Space Spraying on the Transmission of Dengue/Dengue Hemorrhagic Fever (DF/DHF) in an Urban Area of Southern Thailand. J Trop Med 652564. doi: $10.1155 / 2012 / 652564$.

Thomas SJ, Aldstadt J, Jarman RG, Buddhari D, Yoon I-K, Richardson $\mathrm{JH}$, et al, 2015. Improving dengue virus capture rates in humans and vectors in Kamphaeng Phet Province, Thailand, using an enhanced spatiotemporal surveillance strategy. Am J Trop Med Hyg 93:24-32. doi: 10.4269/ajtmh.140242 .

Tipayamongkholgul M, Fang C-T, Klinchan S, Liu C-M, King CC, 2009. Effects of the El Niño-southern oscillation on dengue epidemics in Thailand, 1996-2005. BMC Public Health 9:422. doi: 10.1186/1471-2458-9-422.

Toan NT, Rossi S, Prisco G, Nante N, Viviani S, 2015. Dengue epidemiology in selected endemic countries: factors influencing expansion factors as estimates of underreporting. Trop Med Int Health 20:840-63. doi: 10.1111/tmi.12498.

Vallee J, Dubot-Peres A, Ounaphom P, Sayavong C, Bryant JE, Gonzalez JP, 2009. Spatial distribution and risk factors of dengue and Japanese encephalitis virus infection in urban settings: the case of Vientiane, Lao PDR. Trop Med Int Health 14:1134-42. doi: 10.1111/j.1365-3156.2009.02319.x.

van Panhuis WG, Choisy M, Xiong X, Chok NS, Akarasewi P, Iamsirithaworn S, et al, 2015. Region-wide synchrony and traveling waves of dengue across eight countries in Southeast Asia. Proc Natl Acad Sci USA 112:13069-74. doi: 10.1073/pnas.1501375112.

Vanwambeke SO, van Benthem BHB, Khantikul N, BurghoornMaas C, Panart K, Oskam L, et al, 2006. Multi-level analyses of spatial and temporal determinants for dengue infection. Int J Health Geogr 5:5. doi: 10.1186/1476-072X-5-5.

Villar LA, Rojas DP, Besada-Lombana S, Sarti E, 2015. Epidemiological trends of dengue disease in Colombia (20002011): a systematic review. PLoS Negl Trop Dis 9:e0003499. doi: 10.1371/journal.pntd.0003499.

Vincenti-Gonzalez MF, Grillet M-E, Velasco-Salas ZI, Lizarazo EF, Amarista MA, Sierra GM, et al, 2017. Spatial Analysis of Dengue Seroprevalence and Modeling of Transmission Risk Factors in a Dengue Hyperendemic City of Venezuela. PLoS Negl Trop Dis 11:e0005317. doi: 10.1371/journal. pntd.0005317.

Weiss RA, McMichael AJ, 2004. Social and environmental risk factors in the emergence of infectious diseases. Nature Med 10:S70. doi: 10.1038/nm1150. 
Whitehorn J, Yacoub S, 2019. Global warming and arboviral infections. Clin Med 19:149-52. doi: 10.7861/clinmedicine.19-2149.

WHO, 2018. Asia Pacific Strategy for Emerging Diseases (APSED) Evaluation Report (2005-2015). World Health Organization.

Xu Z, Bambrick H, Yakob L, Devine G, Lu J, Frentiu FD, et al, 2019. Spatiotemporal patterns and climatic drivers of severe dengue in Thailand. Sci Total Environ 656:889-901. doi: 10.1016/j.scitotenv.2018.11.395.

Yoon IK, Getis A, Aldstadt J, Rothman AL, Tannitisupawong D, Koenraadt CJM, et al, 2012. Fine scale spatiotemporal clustering of dengue virus transmission in children and Aedes aegypti in rural Thai villages. PLoS Negl Trop Dis 6:e1730. doi: 10.1371/journal.pntd.0001730. 